\title{
Bina Iman Remaja Dalam Masa Pandemi Covid-19 di Paroki Santa Maria Immaculata Mataram
}

\author{
Pedro Agus Dwi Juniantara Ramos ${ }^{1} \mid \underline{\text { ramosdeleste15@gmail.com }}$ \\ Antonius Denny Firmanto ${ }^{2} \mid \mathrm{rm}$ deni@yahoo.com \\ Nanik Wijiyati Aluwesia ${ }^{3}$ nanikwa9@gmail.com \\ ${ }^{1,2,3}$ Sekolah Tinggi Filsafat Teologi Widya Sasana Malang \\ Jawa Timur-Indonesia
}

\begin{abstract}
This paper focuses on the activities of Bina Iman Remaja (BIR) during the pandemic. Adolescent Faith Building is a form of Categorial Catechesis of the Ummah. The covid-19 pandemic is bringing big changes to the world and people. Starting to have restrictions on community activities to reduce the rate of spread of covid-19. Many community activities are limited, even canceled for an indefinite period. The Church cannot avoid this because the Church is in the middle of the world. The church has also responded to this situation by taking a policy to conduct several ecclesiastical activities online. One of the activities carried out online is Youth Faith Development. The methodology that the researcher uses in making this paper is a qualitative method, namely by conducting personal interviews with respondents. My finding in this study is that online Youth Faith Development activities are not effective for the development of the faith of Catholic Youth.
\end{abstract}

Keywords: Youth Faith Development, Youth, Pandemic, Technology

\begin{abstract}
Abstrak
Tulisan ini berfokus pada kegiatan Bina Iman Remaja (BIR) selama masa pandemi. Bina Iman Remaja merupakan salah satu bentuk dari Katekese Kategorial Umat. Pandemi covid-19 membawa perubahan besar bagi dunia dan manusia. Mulai adanya pembatasan kegiatan masyarakat guna menekan laju penyebaran covid-19. Banyak kegiatan masyarakat yang dibatasi, bahkan ditiadakan untuk waktu yang tidak ditentukan. Gereja tidak bisa menghindari hal ini karena Gereja ada di tengah dunia. Gereja pun menanggapi situasi ini dengan mengambil kebijakan untuk melakukan beberapa kegiatan gerejawi secara online. Salah satu kegiatan yang dilakukan secara online adalah Bina Iman Remaja. Metodologi yang peneliti gunakan dalam pembuatan tulisan ini adalah metode kualitatif, yakni dengan melakukan wawancara pribadi dengan responden. Temuan saya dalam penelitian ini ialah bahwa kegiatan Bina Iman Remaja yang dilakukan secara online tidak efektif bagi perkembangan iman kaum Remaja Katolik.
\end{abstract}

Kata Kunci: Bina Iman Remaja, Kaum Remaja, Pandemi, Teknologi

\section{Latar Belakang}

Katekese merupakan salah satu sarana yang ampuh untuk menumbuhkan dan mengembangkan iman Gereja. Katekese bertugas menghadirkan sabda Allah agar manusia bertemu secara pribadi dengan Kristus (Marinus, 1999: 9). Bina iman merupakan salah satu bentuk katekese di dalam Gereja. Tulisan ini akan membahas mengenai Bina Iman Remaja selama pandemi covid-19. Selama masa pandemi ini, banyak kegiatan gerejawi yang dibatasi bahkan ditiadakan. Hal ini berkaitan dengan protokol kesehatan yang ada. Salah satunya adalah kegiatan Bina Iman Remaja. Gereja mencari solusi untuk mengatasi permasalahan yang muncul akibat pandemi ini. Dengan bantuan teknologi, Gereja akhirnya bisa mengatasi permasalahan tersebut. 
Dalam masa pandemi sekarang ini, banyak sekolah yang harus tutup menanggapi kebijakan social distancing yang dikeluarkan oleh pemerintah. Berkaitan dengan hal ini, pihak Kementrian Pendidikan dan Kebudayaan (Kemdikbud) mengambil kebijakan belajar dari rumah (Gogot, 20 Maret 2021). Kemdikbud menerapkan kelas online yang memungkinkan setiap murid sekolah untuk belajar dari rumah mereka. Hal ini merupakan suatu terobosan yang baru dan baik dibidang pendidikan. Kebijakan belajar dari rumah sangat membantu baik pemerintah maupun masyarakat yang dalam konteks ini adalah para murid sekolah. Kebijakan belajar dari rumah bisa terlaksana dengan baik karena didukung oleh teknologi dan internet saat ini. Idealnya, kelas online seperti ini tidak berbeda jauh dengan kelas tatap muka biasanya dan tentu efektif bagi para murid sekolah, secara khusus kaum remaja. Hal ini karena sebagian besar kaum remaja bisa menguasai dan memanfaatkan teknologi dengan baik untuk berbagai keperluan. Mereka mungkin tidak akan mengalami kendala berdasarkan alasan tersebut.

Sekilas memang terlihat bahwa generasi milenial atau kaum remaja sekarang ini, tidak mengalami kendala berkaitan dengan kelas online. Namun jika ditelisik lebih dalam, sebenarnya kaum remaja sekarang ini memiliki kendala sehubungan dengan kelas online. Para pelajar, secara khusus kaum remaja, merasa 'kaget' dengan kebijakan yang diambil oleh Kemdikbud mengenai kelas online. Sehingga terkadang kelas online serasa tidak efektif bagi sebagian besar kaum pelajar di Indonesia. Model pembelajaran daring (dalam jaringan) kurang efektif untuk dilakukan karena para pelajar belum terbiasa untuk melakukan pembelajaran di rumah dan bukan di sekolah (Melania, 20 Maret 2021). Tidak bisa dipungkiri bahwa para pelajar saat ini merupakan generasi yang sangat dekat dengan kemajuan teknologi.

Bina iman remaja yang dilakukan secara online memang terdengar menarik. Tentu banyak hal bisa terjadi ketika bina iman dilakukan secara online. Kaum remaja mungkin akan berharap bahwa bina iman secara online akan melibatkan koreografi dan animasi yang menarik dan memanjakan mata. Namun ketika kegiatan bina iman online berlangsung, tidak sedikit dari mereka yang malahan tidak menyimak dengan baik atau memerhatikan berlangsungnya kegiatan bina iman online tersebut. Berkaitan dengan itu, peneliti ingin meneliti mengenai beberapa hal yang dirumuskan dalam tiga rumusan masalah, antara lain: Mengapa banyak kaum remaja yang tidak mengikuti kegiatan bina iman dengan baik? Apakah bina iman secara online efektif untuk mengembangkan pengetahuan iman kaum remaja? Manakah yang lebih efektif untuk kaum remaja: bina iman secara online atau bina iman offline?

Memang tidak ada penelitian terdahulu mengenai Bina Iman Remaja selama masa pandemi. Namun Bina Iman Remaja secara online bisa disejajarkan dengan sekolah online selama masa pandemi. Sebab kedua hal tersebut merupakan pendidikan yang dilangsungkan selama masa pendemi ini. Tujuan dari penelitian ini adalah memberi kejelasan mengenai efektifitas kegiatan Bina Iman Remaja selama masa pandemi sekarang ini.

\section{Metode Penelitian}

Tulisan ini disusun dengan menggunakan metode kualitatif. Pengumpulan data secara kualitatif dilakukan dengan metode wawancara. Peneliti melakukan wawancara secara individu atau pribadi antara peneliti dengan responden yang sudah ditentukan. Peneliti melakukan wawancara terhadap responden yang berperan sebagai pembimbing bina iman remaja di Paroki St. Maria Immaculata, Mataram, Lombok. Adapun responden yang melakukan wawancara secara pribadi dengan peneliti berjumlah 5 orang. Dari 5 responden yang ada, 2 di antaranya 
adalah mahasiswa yang saat ini menempuh pendidikan di Universitas Mataram dan 3 responden lainnya sudah bekerja.

\section{Hasil Dan Pembahasan}

\section{Generasi Milenial}

Belakangan generasi milenial sekarang ini menjadi bahan perbicangan di berbagai media. Generasi milenial ini memiliki banyak kebiasaan yang sangat berbeda dengan generasigenerasi milenial sebelumnya. Dengan ini nama generasi milenial semakin luas dibicarakan dari berbagai sisi dan dalam berbagai media, entah itu media cetak ataupun media masa. Perlu untuk disadari bahwa ada tiga golongan generasi milenial, antara lain: The Student Millennials, The Working Millennials, dan The Family Millenials.

The Student Millennials. Mereka adalah kelompok milenial yang lahir pada rentan tahun dari 1993 sampai dengan tahun 2000 (Sebastian, 2016: 12). Mereka ini merupakan generasi milenial yang masih dalam masa-masa sekolah atau sebagai seorang pelajar. Mereka yang masuk dalam golongan ini rata-rata sudah mengenal smartphone sejak mereka masih kecil. Mereka sudah akrab dengan teknologi sedari kecil, dan tidak bisa dipungkiri bahwa mereka hidup dan berkembang bersama teknologi.

The Working Millenials. Kelompok kedua adalah kelompok generasi yang lahir pada rentangan tahun 1987 sampai dengan tahun 1993 (2016: 13). Kelompok kedua ini merupakan kelompok milenial yang hidup bersama dengan teknologi juga. Mereka adalah kelompok milenial yang berada pada masa-masa kerja.

The Family Millenialls. Kelomok ketiga ini merupakan kelompok milenial yang sudah berkeluarga ataupun kelompok milenial yang masih merencanakan untuk menikah (2016: 14). Kelompok milenial ini mengalami masa sekolah yang menjadi masa transisi. Masa transisi yang dimaksud di sini adalah masa transisi dari analog ke digital.

Kaum remaja saat ini tergolong ke dalam The Student Millenials. Mereka ini tumbuh dan berkembang bersama dengan teknologi. Sebagian besar dari mereka selalu ditemani oleh teknologi setiap hari, sehingga teknologi bukanlah hal yang asing bagi mereka. Teknologi seakan-akan menjadi sahabat bagi mereka. Apa pun yang mereka inginkan disediakan oleh sahabat mereka, yakni teknologi. Mulai dari kebutuhan primer sampai pada kebutuhan sekunder, semuanya dapat dijangkau dengan mudah.

Meskipun remaja berusaha untuk memperoleh otonomi, ia sebenarnya masih membutuhkan orang lain untuk menginspirasi dan membimbingnya (Utomo, 2018: 2). Mereka berada pada tahap mencari identitas diri. Mereka biasanya akan mencari seseorang untuk dijadikan contoh atau pedoman mereka. Maka orang dewasa di sekitar mereka perlu menyadari hal ini, secara khusus orang tua. Mereka menginginkan dukungan dan bimbingan dari orang dewasa di sekitarnya.

\section{Dunia Milenial}

Sekarang ini dunia sedang mengalami perubahan pesat di berbagai bidang. Kemajuan dan perkembangan teknologi menjadi penyebab terbesar dari perubahan dunia saat ini. Teknologi menawarkan kemudahan bagi manusia. Salah satu contoh kemudahan yang marak dibicarakan belakangan ini adalah kemudahan dalam berbelanja. Ecommerce atau Electronic commerce merupakan aktivitas jual beli yang dilakukan melalui media elektronik yang mana 
sekarang sering dilakukan di internet (Nayoan, 20 Maret 2021). Tokopedia, Lazada, Shopee, Blibli, dan Bukalapak; itu semua merupakan contoh toko online yang banyak digunakan di Indonesia.

Teknologi membuka kemungkinan seluas-luasnya untuk belajar sesuatu. Dari mulai kursus, pelatihan untuk keahlian tertentu, kelas terbuka, sampai mendapatkan gelar diploma atau sarjana, bisa ditempuh secara online (2016: 66). Hal ini ditandai dengan adanya banyak seminar dan kursus yang diadakan secara online. Faktanya bahwa tidak sedikit kaum remaja yang menyukai e-learning seperti ini. Dari sini dapat ditarik sedikit kesimpulan bahwa sebagian besar kaum remaja menyukai e-learning dari pada pembelajaran tatap muka yang biasanya dilakukan. Teknologi dan jaringan internet seperti sekaranglah yang memungkinkan terwujudnya semua hal itu.

Usaha terus menerus pemutakhiran dan konvergensi teknologi sungguh-sungguh membuka kemungkinan yang sangat luas untuk mengembangkan cara kerja manusia di semua bidang kehidupan (Wijanarko, 2019: 115). Pengembangan teknologi membawa perubahan dalam segala bidang kehidupan manusia. Misalnya pengembangan teknologi di bidang kedokteran. Dengan berkembangnya teknologi, para dokter terbantu dalam mendiagnosis penyakit yang dialami oleh seseorang dengan lebih akurat. Manusia menjadi sangat terbantu dengan perkembangan teknologi yang terjadi secara terus menerus ini.

Sekarang ini dunia sedang dilanda pandemi covid-19 yang membatasi ruang gerak setiap orang. Setiap orang diminta untuk menjaga jarak, menjauhi kerumunan, menjaga kebersihan lingkungan dan diri, serta senantiasa memakai masker. Slogan stay at home menjadi suatu slogan yang sering diserukan oleh sebagian besar orang. Muncul persoalan baru, bagaimana caranya seseorang menghasilkan uang, bagaimana cara agar para pelajar bisa tetap belajar dan masih banyak pertanyaan lain berkaitan dengan situasi dan kondisi saat ini. Teknologi dan internet menjadi jawaban atas semua pertanyaan tersebut. Ketika ingin belajar, tinggal membuka browser dan mencari apa yang hendak dipelajari. Tidak bisa dipungkiri bahwa manusia menjadi sangat tergantung akan teknologi dan internet. Seakan-akan ketika tidak ada teknologi dan internet, manusia tidak bisa bertahan hidup.

\section{Katekese Kategorial Remaja}

Katekese adalah usaha-usaha dari pihak Gereja untuk menolong umat agar semakin memahami, menghayati, dan mewujudkan imannya dalam kehidupan sehari-hari (1999: 5). Dengan kata lain, katekese merupakan suatu kegiatan yang dilakukan pihak Gereja untuk mengembangkan dan memperkukuh iman umat. Di dalam kegiatan katekese terdapat beberapa aspek yakni aspek pewartaan, aspek pengajaran, aspek pembinaan, dan aspek penguatan. Melalui katekese, Gereja hendak membimbing dan mengarahkan umat agar selalu berjalan di jalan yang baik.

Katekese Umat merupakan perpaduan antara penghayatan iman yang bersumber dari pengalaman hidup sehari-hari dan pengetahuan iman yang bersumber dari permenungan Kitab Suci dan Ajaran Gereja (Firmanto, 2018: 240). Katekese berhubungan erat dan tidak terlepas dari kehidupan keseharian umat. Biasanya katekese menghubungkan antara pengalaman hidup dan Kitab Suci serta Ajaran Gereja. Katekese memiliki 3 tugas utama, antara lain: memberitakan Kristus, mendidik umat untuk beriman, dan mengembangkan Gereja (1999: 9). 
Pertama, katekese bertugas untuk memberitakan Yesus Kristus. Sudah tentu bahwa katekese bertujuan untuk membimbing umat agar beriman kepada Yesus Kristus. Kehidupan Yesus tertulis secara ringkas di dalam Kitab Suci. Sebagai orang beriman, Kitab Suci hendaknya menjadi buku rohani dan menjadi salah satu sumber untuk mengenal Yesus secara lebih mendalam. Maka perlu adanya bimbingan yang baik sehingga umat bisa mengenal siapa yang mereka imani. Kedua, katekese bertugas mendidik umat untuk beriman. Iman adalah jawaban manusia terhadap karya keselamatan Allah. Beriman kepada Allah mengandaikan seseorang percaya dan berserah kepada Allah. Perlu disadari bahwa manusia sekarang ini sulit untuk mempercayai apa yang tidak mereka lihat. Hal ini didukung oleh kemajuan dan perkembangan teknologi. Kadang kala juga manusia tidak mempercayai apa yang mereka lihat, apalagi sesuatu yang tidak bisa mereka lihat dengan mata telanjang. Di sinilah tugas katekese untuk mendidik umat sehingga mereka benar-benar beriman kepada Allah, yang tidak bisa mereka lihat. Ketiga, katekese bertugas untuk mengembangkan Gereja. Katekese memiliki aspek pewartaan sehingga dalam katekese terdapat unsur-unsur pewartaan iman. Dengan pewartaan, Gereja membuka sayapnya lebar-lebar bagi orang-orang yang ingin berteduh di bawahnya. Perkembangan Gereja bergantung pada pewartaan yang mereka lakukan, sehingga pewartaan menjadi salah satu bidang yang penting di dalam Gereja.

Katekese kategorial remaja yang biasa dilakukan berbagai paroki di Indonesia adalah Bina Iman Remaja (BIR). Bina Iman Remaja merupakan salah satu kegiatan katekese umat yang secara khusus ditujukan untuk kalangan Remaja Katolik. Bina Iman Remaja ini sangat popular saat ini dibandingkan dengan katekese kategorial lainnya. Tentu sangat diharapkan agar Bina Iman Remaja dapat terlaksana dengan baik. Sehingga apa yang ingin disampaikan oleh para pembimbing dapat ditangkap dan dipahami oleh kaum Remaja Katolik. Maka dari itu, para pembimbing perlu untuk menyadari siapa itu kaum remaja saat ini, apa yang mereka inginkan dan bagaimana cara menyampaikan sesuatu secara baik kepada mereka.

Bina Iman Remaja bertujuan untuk membimbing kaum Remaja Katolik, sehingga mereka bisa mencapai kedewasaan iman. Iman yang dewasa juga diartikan sebagai iman yang berkembang semakin matang secara penuh dan bersifat holistik karena mencakup segi pemikiran, hati, dan praksis (Team, 2019: 15). Demi mencapai tujuan tersebut, yakni kedewasaan iman, tentu bahan atau materi yang disampaikan dalam bina iman hendaknya bisa dimengerti dengan baik oleh kaum remaja. "Supaya engkau dapat mengetahui, bahwa segala sesuatu yang diajarkan kepadamu seungguh benar" (Luk. 1: 4).

Dalam kegiatan berkatekese, peran seorang katekis tentu sangat dibutuhkan. Seorang katekis berperan menuntun umat beriman untuk mengerti dan memahami iman mereka secara lebih mendalam. Para katekis hendaknya memiliki beberapa keterampilan seperti menyadari pengalaman hidup, menyadari pengalaman iman yang direfleksikan dalam terang Kitab Suci, menyadari pengalaman iman yang direfleksikan dengan Tradisi dan ajaran Gereja, menyadari bagaimana keterlibatan Gereja dalam hidup bermasyarakat (Budianto, 2019: 210). Daniel Boli Kotan (diakses, 22 Maret 2021), menuliskan tugas dari seorang katekis, antara lain: sebagai guru agama, pendamping dalam katekese keluarga, memimpin doa-doa dan ibadat sabda dalam Komunitas Basis Gerejawi (KBG), memberikan pelayanan komuni bagi orang sakit, membantu pengelolaan pastor paroki, melatih orang lain untuk menjadi katekis, memberikan teladan kehidupan yang baik. Dilihat dari tugas-tugasnya, peran seorang katekis sangat berarti dalam kegiatan katekese. 


\section{Hasil Penelitian}

Pengumpulan data yang digunakan oleh peneliti adalah dengan melakukan wawancara dengan 5 responden. Semua responden itu merupakan kakak pendamping Bina Iman Remaja di Paroki St. Maria Immaculata, Mataram, Lombok. Adapun berikut hasil dari wawancara pribadi yang dilakukan antara peneliti dengan kelima responden.

1. Bagaimana perasaan Anda selama mempersiapkan kegiatan Bina Iman Remaja online?

Responden pertama merasa senang karena teman-teman pendamping bina iman yang lain sangat antusias dalam proses pembuatan konten bina iman, meskipun terkadang melelahkan. Terlebih lagi ketika pembuatan konten untuk masa prapaskah ini. Kami mengajak paroki tetangga untuk bekerja sama membuat konten untuk bina iman online ini. Jujur saja, saya merasa senang saat itu, karena sebelumnya kami hanya membuat konten sendiri.

Responden kedua merasa sangat bersemangat. Saya selalu antusias dalam proses pembuatan konten bina iman, selain itu saya juga berusaha menggerakkan teman-teman lain untuk ikut bersemangat juga.

Responden ketiga merasa senang karena kita bisa menyapa adik-adik remaja lagi meskipun hanya secara virtual atau online. Disamping itu juga ada rasa seru karena bisa mengajak beberapa adik remaja untuk ikut dalam pembuatan konten bina iman. Meskipun tidak bisa mengajak semuanya, tapi tetap saya merasa senang. Selain itu saya juga bersyukur bahwa adik-adik remaja mengikuti kegiatan bina iman online. Mengingat bahwa setiap hari mereka juga mengikuti kelas online dan tentu menguras cukup banyak data internet. Namun mereka menyempatkan diri untuk menonton konten bina iman yang sudah kami buat.

Responden keempat merasa bahwa bina iman online lebih menantang dari pada bina iman offline. Mengapa demikian? Jujur saja karena saya pribadi belum terbiasa untuk berbicara berhadapan dengan kamera dan itu harus dilakukan dalam bina iman online.

Responden kelima bahwa bina iman online itu berbeda dengan bina iman offline. Itu karena kakak-kakak pendamping dituntut untuk lebih menghafal dan menguasai bahan yang akan disajikan dalam bina iman online. Kami diharuskan untuk berpikir keras untuk mencari bahan dan menyajikannya dalam konten bina iman semenarik mungkin.

2. Apa saja hambatan yang dihadapi selama mempersiapkan kegiatan bina iman online?

Menurut responden pertama, ada dua hambatan yang dialami selama mempersiapkan kegiatan bina iman online. Pertama, semangat dari beberapa teman pendamping lain yang semakin lama, semakin menurun. Awalnya sangat antusias, seiring berjalannya waktu semakin menurun, bahkan sampai ada yang tidak ikut berpartisipasi lagi. Kedua, ketika ada teman yang dihadapkan bisa untuk mengisi suatu sesi, ternyata berhalangan dan harus mencari pendamping lain untuk penggantinya. Padahal orang tersebut merupakan 'langganan' untuk sesi tersebut. Ketika harus mencari pengganti, akan sulit bagi kami. Tentu saya tidak bisa memaksa teman-teman pendamping yang lain untuk selalu ikut berpartisipasi dalam pembuatan konten bina iman. Apalagi belakangan ini, masing-masing dari kami mulai sibuk entah sibuk bekerja maupun sibuk kuliah. Jadi tidak bisa menekan teman yang lain untuk berpartisipasi terus.

Menurut responden kedua, ada tiga hambatan yang dihadapi. Pertama adalah sulitnya mencari talent. Maksudnya adik-adik Bina Iman Remaja yang bisa diikutsertakan dalam 
pembuatan konten bina iman. Selama masa pandemi seperti ini, sangat sulit untuk mendapatkan izin dari orang tua mereka. Tetapi syukurlah para orang tua adik-adik remaja mempercayai kami sehingga beberapa adik remaja bisa ikut serta dalam pembuatan konten bina iman. Kendala kedua yang dihadapi adalah ide yang sulit sekali muncul. Kadang ideide 'gila' akan muncul ketika sudah di ujung tanduk. Sehingga kadang harus berusaha ekstra keras agar konten bina iman tersebut dapat terselesaikan dengan baik dan tepat waktu. Hambatan ketiga muncul ketika proses editing konten bina iman. Jujur saja, pada awal memulai kegiatan bina iman secara online, kami merasa kesulitan karena hanya ada satu orang saja yang menjadi tumpuan. Sekarang saya bersyukur karena sudah cukup banyak kakak pendamping yang bisa mengambil alih proses editing video bina iman.

Menurut responden ketiga, selama mengikuti proses pembuatan konten, hambatannya adalah waktu. Rata-rata kakak pendamping sudah bekerja dan ada beberapa yang sedang kuliah. Jadi memang harus mencari waktu bersama-sama agar semua bisa berpartisipasi, meskipun tidak semua bisa. Kadang kala bisa melakukan rekaman sampai malam.

Menurut responden keempat, kendala yang dihadapi adalah sulitnya menentukan bahan serta bagaimana cara mengemas bahan tersebut agar menarik bagi kaum remaja. Selain itu, kendala lainnya adalah kita tidak bisa memastikan bahwa semua adik-adik remaja menonton konten bina iman yang sudah kami upload di Youtube.

Menurut responden kelima, hambatan pertama adalah sulitnya mengumpulkan kakak-kakak pendamping entah untuk Menyusun koreografi ataupun untuk mengerjakan konten bina iman. Hambatan kedua adalah belum tentu adik-adik remaja mengikuti atau menonton konten bina iman yang sudah kami buat.

3. Jika ada tugas, apakah kaum remaja mengerjakan tugas yang diberikan dengan baik?

Menurut responden pertama, tidak semua adik-adik remaja mengerjakan tugas yang diberikan dengan baik. Masih ada beberapa adik remaja yang malahan tidak mengerjakan tugas yang kami berikan. Melihat hal ini, kami memiliki ide untuk memberikan hadiah bagi mereka yang paling cepat mengumpulkan tugas. Misalnya dengan memberikan souvenir ataupun memberikan kuota internet.

Menurut responden kedua, tugas selalu ada pada bagian akhir yakni Tugas Perutusan, sesuai dengan modul yang ada. Tugasnya dikumpulkan secara online. Ada macam-macam tugas yang diberikan, salah satunya tugas teka-teki silang. Biasanya diberi waktu satu hari untuk mengerjakan dan tiga atau lima orang pertama yang mengumpulkan tugas ke kakak pendamping, akan diikutsertakan dalam pembuatan video bina iman selanjutnya. Mereka sangat antusias dan bangga karena masuk youtube. Malahan tugas yang sebelumnya yakni membuat kotak APP, banyak yang tidak mengerjakan. Mungkin karena mereka sudah mulai masuk sekolah dan tugas juga banyak, jadi mungkin mereka lupa. Malahan adikadik bina iman anak yang lengkap membuat dan mengumpulkannya.

Menurut responden ketiga, setiap kegiatan bina iman ada tugas yang diberikan. Ada adik-adik remaja yang mengumpulkan, ada juga yang kelupaan. Sehingga tidak mengerjakan dan tidak mengumpulkannya. Kami juga memaklumi dan tidak terlalu menuntut mereka mengerjakannya. Sedangkan ketika bina iman offline lebih mudah karena mereka mengerjakan tugasnya ketika pertemuan. 
Menurut responden keempat, tidak semua adik-adik remaja mengerjakan tugas-tugas yang diberikan. Kemudian kami memiliki ide untuk memotivasi mereka mengerjakan tugas, yakni dengan memberikan feedback. Memang kemudian mereka mengerjakannya dengan bersemangat, akan tetapi semakin lama, semangat mereka semakin menurun.

Menurut responden kelima, Hampir semua adik-adik remaja mengerjakan tugas yang diberikan. Meskipun demikian, tidak semua dari mereka mengerjakan tugas yang diberikan dengan baik.

4. Menurut Anda, apakah bina iman online seperti ini efektif bagi kaum remaja?

Menurut responden pertama, untuk saat ini bina iman seperti ini cukup efektif karena situasi yang tidak mendukung untuk melakukan bina iman offline. Sekarang ini saya melihat adanya kebosanan karena kegiatannya bisa dikatakan hanya menonton konten begitu saja, tidak terlibat langsung dalam kegiatan bina iman.

Menurut responden kedua, Bina Iman Remaja secara online seperti ini tidak efektif, akan lebih efektif untuk Bina Iman Anak. Kaum remaja merasa bahwa bina iman seperti ini membosankan dan monoton. Mereka lebih menyukai Tiktok ketimbang bina iman online. Gerakan di tiktok berbeda dengan gerakan misioner yang memiliki aturannya sendiri.

Menurut responden ketiga, berbicara mengenai efektif atau tidak efektifnya mungkin lebih baik dikaitkan dengan situasi dan kondisi. Memang selama pandemi ini yang membatasi ruang gerak, mobilitas dan tatap muka dengan orang lain. Bina iman online seperti ini bisa dikatakan cukup efektif, karena sekolah-sekolah pun berbasis online. Sebenarnya masalah efektif atau tidak efektifnya berkaitan dengan situasi dan kondisi yang ada.

Menurut responden keempat, kegiatan bina iman online seperti ini tidak efektif apalagi untuk kaum remaja. Mereka memiliki kesibukannya sendiri dan akhirnya jarang untuk menonton konten bina iman yang sudah dibuat.

Menurut responden kelima, bina iman online tidak efektif bagi kaum remaja. Hal ini karena adik-adik remaja belum tentu menonton konten yang kami buat hingga selesai. Kadang kala saya menanyakan apakah mereka sudah menonton konten yang kami buat dan mereka menjawab bahwa mereka hanya menonton sebentar saja. Kami pernah berpikir untuk membuat pertemuan bina iman secara virtual melalui zoom atau Google Meet. Namun kami memikirkan keadaan adik-adik yang sudah seharian berhadapan dengan kedua aplikasi tersebut. Jadi kami membatalkan niat kami tersebut.

5. Menurut Anda, manakah yang lebih efektif: bina iman online atau bina iman offline? Apa alasannya?

Menurut responden pertama, bina iman secara langsung atau bertatap muka akan jauh lebih efektif dari pada bina iman online. Ketika bina iman tatap muka, kita bisa menyapa adik-adik secara langsung. Bahasa tubuh mereka akan berbeda ketika bertemu dengan para kakak pendamping, dengan kakak-kakaknya, dan dengan teman-temannya. Sapaannya juga berbeda, kita bisa melihat keadaan adik-adik secara langsung. Saya yakni bina iman tatap muka jauh lebih efektif dan saya percaya adik-adik juga sudah rindu ingin berkumpul kembali dalam kegiatan Bina Iman Remaja.

Menurut responden kedua, bina iman offline lebih efektif. Kalau bina iman online, kita hanya bisa melihat kuantitas, berapa banyak yang menonton konten bina iman yang 
kami buat. Mereka yang menontonnya pun belum tentu menontonnya hingga selesai. Tetapi jikalau secara langsung, kita bisa memastikan mereka memperhatikan dari awal sampai akhir kegiatan.

Menurut responden ketiga, yang lebih efektif adalah bina iman offline. Kita bisa mendengarkan Sabda Allah secara langsung dan kita juga bisa sharing dari Kitab Suci secara langsung. Selain itu, interaksi adik-adik remaja yang satu dengan yang lain terasa lebih hidup dan ekspresif, sehingga relasi mereka lebih terjaga. Ketika berbasis online seperti ini, mereka cenderung fokus ke handphone mereka masing-masing. Namun ketika bertemu secara langsung, mereka bisa berbicara bersama, mereka bisa saling membagikan pengalaman selama di rumah dan di sekolah. Saya juga merasa bahwa mereka sangat rindu untuk mengikuti bina iman offline seperti yang biasanya dilakukan.

Menurut responden keempat, bina iman secara langsung lebih efektif. Itu karena kita bisa berinteraksi dengan adik-adik remaja secara langsung. Selain itu, terasa lebih seru jika bisa bertemu secara langsung.

Menurut responden kelima, bina iman secara langsung jauh lebih efektif. Meskipun kaum remaja yang datang hanya sedikit, tetapi kita bisa mengamati mereka secara langsung. Selain itu, kita bisa bertatap muka langsung dan berinteraksi dengan mereka, sedangkan bina iman online, kita bertatap muka dengan kamera.

a. Mengapa banyak kaum remaja yang tidak mengikuti kegiatan bina iman dengan baik?

Selama masa pandemi, kegiatan Bina Iman Remaja tetap diadakan meskipun secara online. Bagaimana caranya? Kakak-kakak pendamping sudah membuat konten untuk Bina Iman Remaja, dan adik-adik tinggal menonton konten tersebut. Paroki St. Maria Immaculata Mataram masih tetap mengadakan kegiatan Bina Iman Remaja, meskipun itu dilakukan secara online. Hal ini perlu untuk disyukuri, mengingat bahwa ada beberapa paroki lain yang masih belum mengadakan kegiatan Bina Iman Remaja.

Sangat disayangkan bahwa tidak semua kaum remaja di Paroki St. Maria Immaculata Mataram mengikuti kegiatan Bina Iman Remaja tersebut. Dari hasil wawancara, ditemukan bahwa kaum remaja lebih menyukai bahwa kaum remaja lebih menyukai kegiatan Bina Iman Remaja yang diadakan secara langsung. Mengapa demikian? Karena dengan demikian, mereka bisa bertemu secara langsung, bercerita secara langsung, bersenda gurau secara langsung dan tidak hanya dilakukan secara online. Disamping itu, kaum remaja lebih suka berselancar di internet dan mencari halhal yang menyenangkan dari pada menonton konten bina iman yang dibuat oleh pendamping mereka. Alasan lain ialah mulai munculnya rasa bosan pada kaum remaja. Hal ini karena mereka bersekolah secara online selama kurang lebih seminggu, kemudian mereka harus mengerjakan tugas ini dan itu. Mereka merasa lelah dan lebih ingin menghibur diri mereka dengan bermain tiktok, bermain game, atau kegiatan menyenangkan lainnya.

b. Apakah bina iman secara online efektif untuk mengembangkan pengetahuan iman kaum remaja?

Berbicara mengenai efektif atau tidaknya kegiatan Bina Iman Remaja secara Online, harus dikaitkan juga dengan situasi dan kondisinya. Selama masa pandemi, tidak ada pilihan selain melaksanakan kegiatan Bina Iman Remaja secara online. Itu merupakan satu-satunya cara agar kegiatan Bina Iman Remaja dapat terus dijalankan. 
Namun, kegiatan Bina Iman Remaja yang dilakukan secara online dinilai tidak bisa mengembangkan pengetahuan iman kaum remaja secara efektif. Hal ini karena sekarang ini, adik-adik remaja sudah mulai bersekolah dan tentu sudah mulai kembali kepada kesibukan mereka di sekolah. Di samping itu, adik-adik remaja pun belum tentu menonton konten bina iman yang sudah dibuat dan upload di youtube. Namun jika dikaitkan dengan situasi dan kondisi pandemi seperti ini, bina iman remaja bisa dikatakan cukup efektif juga dari pada hanya berdiam diri saja.

c. Manakah yang lebih efektif untuk kaum remaja: bina iman secara online atau bina iman offline?

Dari wawancara yang dilakukan, sudah terlihat jelas bahwa Bina Iman Remaja yang dilakukan secara langsung akan jauh lebih efektif dari pada dilakukan secara online. Jika bina iman dilakukan secara online, kita hanya bisa melihat kuantitas yang terlihat dari seberapa banyak kaum remaja yang menonton konten yang dibuat dan kita juga tidak tahu apakah mereka menonton atau mengikuti bina iman sampai selesai atau cuma sebentar saja. Selain itu kaum remaja akan cenderung sibuk ke handphone mereka masing-masing. Sedangkan jika bina iman secara langsung, kita bisa mengamati adik-adik secara langsung, kita bisa mendengarkan Sabda Allah secara langsung dan sharing dari Kitab Suci. Memang hanya sedikit kaum remaja yang mengikuti bina iman, namun terasa lebih efektif dari pada bina iman secara online. Kita bisa berinteraksi dengan mereka secara lebih ekspresif dan hidup, serta kita bisa memastikan mereka mengikuti bina iman dari awal hingga akhir kegiatan.

\section{Pembahasan}

1. Kaum remaja saat ini adalah generasi milenial yang sangat akrab dengan teknologi dan perkembangannya. Hari-hari mereka selalu ditemani oleh teknologi yang menyajikan halhal menarik. Terkadang ketika mereka berkumpul, tidak jarang mereka saling menyombongkan teknologi yang mereka miliki. Ketika seseorang tidak tahu sesuatu yang sedang viral, itu bagaikan orang yang hidup pada zaman sebelum mengenal teknologi.

Saat ini, segala macam informasi terbuka untuk umum dan pasti tersedia di internet. Hal ini berdampak bagi para pengajar seperti guru dan dosen. Para peserta didik benarbenar telah mengalokasikan waktu idealnya untuk sosial media, bukan lagi pengalaman apa yang diterima di ruang-ruang kelas (Riyanto, 2019: 5). Media sosial dianggap bisa menyajikan sesuatu dengan lebih menarik, sehingga benar bahwa banyak para peserta didik yang tidak memperhatikan guru dan dosen secara saksama. Hal seperti ini juga terjadi dalam kegiatan Bina Iman Remaja. Kaum remaja akan cepat merasa bosan jika sesuatu diulang secara terus menerus tanpa adanya pembaruan atau terobosan baru.

2. Iman adalah kebajikan ilahi, olehnya kita percaya akan Allah dan segala sesuatu yang telah Ia sampaikan dan wahyukan kepada kita dan apa yang Gereja kudus ajukan supaya dipercayai (KGK, 451). Iman bukanlah suatu hal yang bisa didapatkan secara instan. Untuk menjadi beriman membutuhkan usaha dan waktu yang panjang, bukan seperti merebus mie instan yang hanya butuh waktu 5 menit. Tidak jarang waktu yang dibutuhkan bahkan sampai setengah umur manusia, mungkin juga lebih dari itu.

Kaum remaja membutuhkan pembimbingan agar bisa menumbuhkan iman mereka secara sehat. Kegiatan Bina Iman Remaja menjadi sarana yang baik untuk 
mengembangkan iman mereka. Perkembangan iman kaum remaja sebagian besar didasari oleh efektif atau tidaknya kegiatan bina iman yang diadakan. Selama masa pandemi, satusatunya cara untuk tetap mengadakan kegiatan bina iman adalah secara online. Namun bina iman secara online dirasa kurang efektif bagi kaum remaja. Kaum remaja yang mengikuti bina iman secara online belum tentu mengikuti kegiatan bina iman tersebut dengan saksama. Penyebabnya karena baik pendidik maupun peserta didik tidak bertemu secara langsung dan tidak ada interaksi secara langsung (Supriyatna, 23 Maret 2021). Keterlibatan kaum muda juga menjadi salah satu faktor yang mempengaruhi efektivitas kegiatan bina iman. Semakin kaum muda enggan terlibat, maka semakin tidak efektif pula bina iman tersebut.

3. Kegiatan bina iman memang akan lebih efektif jika dilakukan secara langsung atau tatap muka. Dalam perjumpaan banyak hal bisa terjadi sehingga kegiatan bina iman tidak terasa monoton dan membosankan. Para pendamping maupun kaum muda bisa melakukan banyak hal dalam bina iman secara langsung.

Konsep mutual (saling/ timbal balik) ini seakan-akan mengukir kebenaran tentang relasionalitas intersubjektif (Riyanto, 2018: 312). Dalam bina iman secara langsung, ada interaksi yang terjadi antara para pendamping dengan kaum remaja dan antara kaum remaja dengan teman-temannya. "Saya sering kali mengundangkan tumbuhnya budaya perjumpaan yang mampu melampaui segala perbedaan dan perpecahan kita" (Fratelli Tutti, 215). Perjumpaan secara langsung dapat meningkatkan efektivitas kegiatan bina iman. Dengan berjumpa secara langsung, kaum remaja bisa ikut terlibat aktif selama kegiatan bina iman. Hal seperti ini tidak dapat ditemukan dalam bina iman yang dilakukan secara online.

\section{Kesimpulan}

Selama masa pandemi seperti ini, kegiatan bina iman dilakukan secara online. Meskipun kaum remaja adalah generasi milenial, namun mereka tidak begitu menyukai kegiatan bina iman secara online. Mereka lebih cenderung untuk menghibur diri mereka sesudah bersekolah selama kurang lebih seminggu. Akibatnya kaum remaja yang mengikuti kegiatan bina iman hanya sedikit dan belum tentu mereka menonton konten bina iman yang sudah dibuat. Mereka mulai merasa bosan, karena bina iman secara online terasa lebih monoton dan membosankan.

Suatu kegiatan pembelajaran menjadi tidak efektif lagi ketika para peserta didik tidak terlibat aktif selama proses pembelajaran tersebut. Ini juga berlaku dalam Bina Iman Remaja. Kaum remaja menjadi enggan terlibat ketika suasana bina iman menjadi membosankan. Maka mereka mencari sesuatu yang bisa membuat mereka merasa semangat kembali, misalnya dengan menonton video di Instagram, youtube dan lain-lain. Suasana yang membosankan menjadi akar dari permasalahan efektivitas bina iman online.

Bina iman secara langsung jauh lebih efektif dari pada bina iman secara online. Hal ini terlihat jelas karena kurangnya interaksi yang terjadi antara para pendamping dengan kaum remaja dan kaum remaja dengan sesamanya. Interaksi yang dimaksud adalah interaksi secara langsung. Dengan interaksi secara langsung, para pendamping bisa mengamati apakah kaum muda mengikuti bina iman dengan baik atau tidak. Sapaan ketika bertemu secara langsung pun akan terasa berbeda dari pada sapaan secara online. 


\section{Daftar Pustaka}

Budianto, A. Sad. (2019). Arah Katekese di Indonesia. Dalam Manik (ed.), Pembaharuan Gereja Melalui Katekese, Malang: STFT Widya Sasana, 204-239.

Firmanto, Antonius Denny. (2018). “Katekese Umat”. Dalam Manik (ed.), Pembaharuan Gereja

Marinus, Telaumbanua. (1999). Ilmu Kateketik: Hakikat, Metode dan Peserta Katekese Gerejawi. Jakarta: Obor.

Riyanto, Armada. (2018). Relasionalitas: Filsafat Fondasi Interpretasi: Aku, Teks, Liyan, Fenomen. Yogyakarta: Kanisius.

Riyanto, Armada. (2019). Percikan” Revolusi 4.0 Refleksi FIlosofis Tentang Siapa Manusia dan Allah, Siapakah Manusia; Siapakah Allah, 1-25.

Sebastian, Yoris. (2016). Generasi Langgas: Millennials Indonesia. (Jakarta: Gagas Media).

Team Katekese Pendidikan Agama Katolik. (2019). Modul Pelatihan Kateketik dan Pendidikan Agama Katolik. Yogyakarta: Universitas Sanata Dharma.

Utomo, Kurniawan Dwi Madyo. (2018). Identitas Diri dan Spiritualitas Pada Masa Remaja. Dalam Manik (ed.), Pembaharuan Gereja Melalui Katekese, Malang: STFT Widya Sasana. $1-13$.

Wijanarko, Robertus. (2019). Revolusi Industri Keempat, Perubahan Sosial, dan Strategi Kebudayaan. Dalam Valentinus (ed.), Siapakah Manusia; Siapakah Allah, Malang: STFT Widya Sasana. 101-116.

\section{Website:}

Melania, Eka Putri. Pembelajaran Daring, Apakah Efektif Untuk Indonesia. https://muda.kompas.id/baca/2020/04/06/pembelajaran-daring-apakah-efektif-untukindonesia/ Diakses pada 20 Maret 2021.

Nayoan, Aldwin, “Apa itu Ecommerce? Kenali Semua Jenis dan Manfaatnya!", https://www.niagahoster.co.id/blog/apa-itu-ecommerce/ Diakses pada 21 Maret 2021.

Suharwoto, Gogot, "Pembelajaran Online di Tengah Pandemi Covid-19, Tantangan yang Mendewasakan",https://pusdatin.kemdikbud.go.id/pembelajaran-online-di-tengahpandemi-covid-19-tantangan-yang-mendewasakan/ Diakses pada 20 Maret 2021.

Supriyatna, Adi, "Pembelajaran Online dan Offline, Mana Lebih Efektif?", https://republika.co.id/berita/qje7v2374/pembelajaran-online-dan-offline-mana-yanglebih-efektif diakses pada 23 Maret 2021.

Kotan, Daniel Boli. (2014). Identitas, Panggilan, dan Spiritualitas Katekis. https://komkatkwi.org/2014/03/06/identitas-panggilan-dan-spiritualitas-katekis/Diaskses pada 22 Maret 2021. 